\title{
Teologi Islam Persepektif Harun Nasution
}

\author{
Muh. Subhan Ashari \\ (Institut Ilmu Al-Quran (IIQ) An-Nur Yogyakarta)
}

\begin{abstract}
Abstrak
Artikel ini menjelaskan pandangan Harun Nasution atas sejarah dan pergolakan pemikiran dalam teologi Islam. Dalam buku "Teologi Islam" Harun Nasution melihat teologi Islam yang diajarkan di Indonesia pada umumnya adalah teologi dalam format ilmu tauhid yang kurang mendalam dan kurang filosofis. Selain itu, teologi Islam yang diajarkan adalah teologi Asy'ariyyah, sehingga timbul kesan di kalangan sementara umat Islam Indonesia bahwa inilah satu-satunya teologi yang ada dalam agama Islam. Dalam buku tersebut Harun Nasution membagi dua bagian. Pertama, Harun Nasution berusaha menjelaskan sejarah timbulnya persoalan-persoalan dalam teologi Islam. Kedua, ia mencoba memberikan analisa dan perbandingan di antara aliran-aliran yang ada dalam Ilmu Kalam. Terakhir, ia mecoba membandingkan fungsi akal dan wahyu antara mazhab Muktazilah dan Asy'ariyyah.
\end{abstract}

This study explains Harun Nasution's view of the history and upheaval of thoughts in Islamic theology. In his book entitled "Islamic Theology", Harun Nasution saw Islamic theology which was taught in Indonesia, in general, as theology in the form of monotheism concept which is less profound and philosophical. In addition, the Islamic theology taught is the Ash'ariyyah theology, so that there is an impression 
among the Indonesian Muslims that this is the only theology that exists in Islam. In his book, Harun Nasution divides Islamic theology into two parts. First, Harun Nasution tried to explain the history of the emergence of problems in Islamic theology. Second, he tried to provide analysis and comparisons among the schools in the Science Kalam. Finally, he tried to compare the functions of reason and revelation between the Muktazilah and Ash'ariyyah schools.

Kata kunci : Teologi, Ilmu Kalam, Harun Nasution

\section{A.Pendahuluan}

Secara bahasa, kata teologi berasal dari bahasa Yunani, yang terdiri dari dua kata yakni theos dan logos. Theos dalam bahasa Yunani berarti Tuhan sedangkan logos berarti ilmu, wacana atau kata. Dengan demikian, teologi bisa dimaknai sebagai ilmu yang mempelajari segala sesuatu yang berkaitan dengan ketuhanan. ${ }^{1}$ Senada dengan hal tersebut, dalam buku Teologi Islam Harun Nasution mengatakan bahwa teologi adalah ilmu yang membahas ajaran-ajaran dasar dari suatu agama, sebagaimana manusia ingin menyelami seluk beluk agamanya secara mendalam. Karena ilmu ini akan memberi mereka keyakinankeyakinan yang berdasarkan pada landasan kuat, yang tidak mudah diombang-ambing oleh peredaran zaman. ${ }^{2}$

Dalam dunia Islam, kita mengenal banyak sekali istilah-istilah atau nama-nama ilmu yang mempelajari ketuhanan, di antaranya ilmu kalâm, fiqih akbar, ilmu ushûluddin, ilmu tauhîd, ilmu aqâid, ilmu tauhîd wa sifât dan ilmu nadzar wa istidlâl. Dari nama-nama tersebut yang paling sering digunakan adalah ilmu kalam. Sedangkan yang paling awal munculnya adalah ilmu fikih akbar. Ilmu fikih akbar pertama kali diucapkan oleh Abu Hanifah. Pada waktu itu, Abu Hanifah berusaha membagi fikih menjadi dua, yaitu fikih akbar dan fikih. Fikih akbar

1 Hasan Mahmud Syafi'i, Al-Madkhal ilâ Dirâsat Ilmi al-Kalâm (Kairo:Makatabah Wahbah, Cet 2, 1991), 260. IX.

2 Harun Nasution, Teologi Islam (Jakarta: Universitas Indonesia Press, Cet 5, 1986), 
diperuntukkan untuk membahas hal-hal yang berbau ketuhanan, sedangkan fikih (saja) diperuntukkan untuk membahas hukum atau syari'at. $^{3}$

Menurut Musyrifah Sunanto, ilmu kalam lahir karena ada dua faktor, pertama untuk menjaga kemurnian ajaran Islam dari serangan agama lain terutama dari Yahudi dan Kristen; kedua untuk memecahkan persoalan agama yang semakin hari semakin rumit dari sisi filsafat dan logika. Kaum Muktazilah berjasa dalam menciptakan ilmu kalam, karena mereka merupakan pembela gigih terhadap Islam dari serangan Yahudi, Nashrani dan para penyembah berhala. Menurut riwayat, mereka mengirim juru-juru dakwah ke segenap penjuru untuk menghadang serangan musuh. Diantara pelopor dan ahli ilmu kalam yang terbesar adalah Washil bin Atho', Abu Huzail alAllaf, Abu Hasan al-Asyari, dan imam Ghazali. ${ }^{4}$

Ahmad Amin dalam bukunya Dhuha Islam menambahi, selain sebab eksternal seperti perluasan Islam dan serangan agama lain, Ilmu Kalam juga lahir karena ada sebab internal yang ada dalam masyarakat Islam sendiri. Ada tiga sebab internal yang diutarakan Ahmad Amin dalam bukunya Dhûha Islâm. Pertama, al-Quran sering menjelaskan konsep monoteisme (keyakinan satu Tuhan) dalam beragama, dan berusaha meruntuhkan konsep-konsep politeisme (keyakinan banyak Tuhan) yang dianut bangsa bangasa Arab saat itu. Ini menunjukan bahwa ada semangat teologi tersendiri dalam alQuran, teologi ini tidak hanya dijelaskan melalui doktrin, tetapi juga logika. Kedua, Dengan keberhasilan umat Islam dalam memperluas wilayahnya, serta mendapat harta yang melimpah dari hasil rampasan perang, maka umat Islam mulai mendapatkan ketenangan. Dari sini mereka mulai berpikir tentang agamanya, dan mulai mengkaji ajaranajaran yang ada dalam al-Quran dan Dan Hadis, terutama dalam permasalahan ketuhanan. Dan sebab yang ketiga yang memprakarsai lahirnya ilmu kalam adalah sebab politik, barangkali ini merupakan

3 Hasan Mahmud Syafi'i, Al-Madkhal ilâ Dirâsat., 26.

4 Musyrifah Sunanto, Sejarah Islam Klasik(Jakarta: Kencana, Cet 3, 2007), 68. 
sebab yang paling nyata dalam melahirkan aliran-aliran teologi dalam Islam. ${ }^{5}$

Di Indonesia ada salah satu pakar teologi Islam jebolanUniversitas Timur dan Barat, namanya Dr. Harun Nasution. Ia mendapat gelar sarjana dari Al-Azhar Mesir, sedangkan gelar doktornya ia dapat dari universitas Mc Gill Kanada. Karenaitu menarik untuk diulas pandangan Harun Nasution atas perkembangan teologi Islam, khususnya yang ada di Indonesia. Dua pengalamannya dari Timur dan Barat diharapkan bisa menjelaskan secara objektif perkembangan teologi Islam,baik kelebihan maupun kekurangannya.

\section{B. Biografi dan Kiprah Intelektual Harun Nasution}

Harun Nasution atau lengkapnya Prof. Dr. Harun Nasution lahir di Pematangsiantar, Sumatra Utara tahun 1919 M. Ia merupakan seorang filsuf muslim kawakan Indonesia. Bisa dikatakan ia merupakan tokoh pelopor pembaharuan Islam di Indonesia, di samping ia juga seorang teolog. Selain sebagai pengajar, ia juga aktif sebagai seorang penulis. Diantara buku-buku yang pernah ia tulis dan telah diterbitkan adalah buku yang berjudul Teologi Islam (1971), Islam ditinjau dari berbagai aspeknya, Filsafat Agama (1973), Pembaharuan dalam Islam; Sejarah Pemikiran dan Gerakan (1975), Akal dan Wahyu dalam Islam (1981), dan Islam Rasionalis (1995). ${ }^{6}$

Pada masa mudanya, Harun Nasution bersekolah di HIS (Hollandsche Indlansche School) dan lulus pada tahun 1934. Kemudian di tahun 1937, ia lulus dari Moderne Ismamietiche Kwekschool,dan melanjutkan pendidikan di Ahliyah Universitas Al-Azhar Mesir pada tahun 1940. Pada tahun 1952, ia meraih gelar sarjana muda di American University of Cairo. Harun Nasution sempat menjadi pegawai Deplu Brussels dan Kairo pada tahun 1953-1960. Setelah itu, ia melanjutkan kuliahnya di Kanada dan mendapatkan gelar doktor dari universitas

5 Ahmad Amin, Dhuha Islam (Kairo: Maktabah al-Usrah, Juz 3, 1997), 1-8.

6 http://id.wikipedia.org/wiki/Harun_Nasutions 
Mc Gill pada tahun 1968. Kemudian pada tahun 1969 ia menjadi rektor di Universitas Negeri Jakarta, dan pada tahun 1973M ia menjadi rektor IAIN Syarif Hidayatullah. Ia wafat di Jakarta tanggal 18 September 1998 M. $^{7}$

Jika melihat sejarah hidupnya, kita bisa menemukan bahwa paling tidak ada tiga budaya besar yang mempengaruhi pemikiran Harun Nasution. Ketiga budaya tersebut adalah budaya Indonesia tepatnya Sumatra Utara sebagai tanah kelahirannya, kemudian budaya Arab Mesir yang menjadi tempat menimba ilmu agama dan yang terakhir tentu budaya Eropa yang menurut penulis paling mempengaruhi dalam corak pemikiran rasionalisnya.

Abad ke Sembilan belas memang merupakan babakan baru dalam pembaruan Islam, setelah Islam hancur lebur pada abad ke tiga belas di tangan Hulagu Khan, dan kemudian muncul tiga kerajaan besar dalam dunia Islam seperti kerajaan Turki Ottoman di Barat Islam, kerajaan Safawi di Persia dan kerajaan Mughal di India. Pembaharuan Islam di Mesir merupakan salah satu gerakan pembaharuan yang pertama dalam dunia modern. Tampaknya, hal ini sangat berpengaruh dalam diri Harun Nasution ketika ia belajar di Kairo. Sehingga Harun Nasution lebih memilih Islam modern yang rasionalis sebagai corak berpikirnya ketimbang Islam tradisional yang dianggapnya jumud.

Dalam catatan penulis, sebenarnya Harun Nasution bukanlah penulis pertama buku ilmu kalam di Indonesia. Jauh sebelum itu, telah ada penulis lain yang cukup popular khususnya di kalangan pesantren. Menurut kajian penulis Imam Nawawi al-Bantani adalah orang yang pertama kali menulis buku tentang ilmu kalam di Indonesia. Muhammad Imam Nawawi al-Jawi al-bantani lahir di Banten, Indonesia pada tahun 1815 - 1897 M. Ia adalah ulama sekaligus intelektual yang terkenal dan sangat produktif dalam menulis kitab. Karyanya meliputi berbagai bidang seperti fikih, tafsir, tasawuf dan ilmu kalam. Tidak kurang dari 115 buku pernah ia tulis. Tentu kalangan pesantren tidak

7 Ibid., 
asing dengan kitab Imam Nawawi seperti Fathul Qarib Syarah Taqrib, Kasyifatus Saja Syarah Safinatun Naja, Sulam Munaja Syarah Safinatus Shalah, Nur al-Dhalam, Tafsir Munir, Tanqihul Qaul dan berbagai kitab lain yang tidak bisa disebutkan semuanya disini.

Dalamilmukalam, Imam Nawawi bahkan menulis beberapa kitab seperti Tîjan al-Durary, Nur al-Dzalam dan Fath al-Majid. Hanya saja, karya Imam Nawawi hampir seluruhnya berbentuk syarah(penjelasan) dari kitab-kitab terdahulu. Tulisan Nawawi sangat identik dengan gaya penulisan ilmu kalam klasik yang penuh dengan logika mantik. Tulisannya juga identik dengan tulisan abad pertengahan yang dipenuhi dengan karya-karya yang berbentuk syarah (menjelaskan dari buku-buku sebelumnya).

Adapun dari pihak luar, sebenarnya ada banyak sekali tokohtokoh muslim yang telah meneliti tentang teologi Islam, baik dari sisi sejarah maupun doktrinnya. Diantaranya adalah Syahrastany dalam bukunya Milal wa Nihal, kemudian Al-Baghdadi yang menulis Al-Farqu bain al-Firaq, Ibnu Hazm dalam bukunya Al-Fasl fî Milal wa al-Ahwâ' wa al-Nihal, Abu Hasan al-Asy'ari dengan karyanya Al-Luma' dan Al-Ibânah an Ushûl al-Diyânah, juga Ibnu Khaldun yang menjelaskan teologi Islam dalam bukunya yang sangat fenomenal yaitu Muqaddimah.

Hanya saja tulisan mereka dalam ilmu kalam masih sering terjebak oleh pembelaan terhadap salah satu kelompok agama tertentu. Penulis tidak tahu apakah karakter penulisan teologi Islam tempo dulu memang mengharuskan demikian atau tidak, barangkali memang ada tantangan yang berbeda dengan saat ini sehingga mereka melakukan demikian. Pada saat itu, mungkin belum ada paham prulalis dalam menyikapi perbedaan antar teologi dalam Islam, sehingga penting memberikan pembelaan-pembelaan terhadap aliran sektenya, demi menjaga kelestarian sekte maupun madzhab masing-masing.

Penelitian tentang teologi Islam juga dilakukan oleh para pemikir kontemporer saat ini, sebut saja Ahmad Amin dalam triloginya Fajru al-Islam, Dhuha al-Islam dan Dhuhûr al-Islam. Dalam buku ini sudah 
tidak ada lagi pembelaan yang akut terhadap golongan tertentu dalam Islam. Pembelaan barangkali sedikit dilakukan Ahmad Amin kepada sekte pengusung rasionalitas dalam Islam seperti Muktazilah, tetapi hal ini dilakukan setelah melihat kenyataan yang ada, bahwa selama ini kelompok yang paling depan dalam membela Islam dari serangan agama lain justru mendapat perlakuan yang tidak adil dari mayoritas umat Islam yang Sunni. Muktazilah dianggap sebagai golongan sesat bahkan kafir karena dianggap terlalu menggunakan logika oleh Ahlu Sunnah.

Dengan demikian tulisan para pemikir kontemporer khususnya yang jebolan barat mulai objektif dalam menulis teologi Islam. Hanya saja untuk kalangan Indonesia, Harun Nasution merupakan orang yang pertama kali dalam menulis sejarah teologi Islam, melalui metode baru yang diambil dari Barat. Metode ini tidak melakukan pembelaan terhadap golongan tertentu, tetapi justru memberikan kelapangan bagi umat Islam untuk memilih aliran atau madzhab yang dianutnya. Perlu diketahui bahwasannya Harun Nasution adalah putra pertama Indonenesia yang mendapat gelar Doktor dalam Islamic Studies di McGill University, Montreal pada tahun $1968 .{ }^{8}$

Menurut Harun Nasution, teologi Islam atau ilmu kalam yang diajarkan di Indonesia pada umumnya adalah teologi yang berbentuk ilmu tauhid. Menurutnya, ilmu tauhid biasanya kurang mendalam dalam pembahasan dan kurang bersifat filosofis. Selain itu, ilmu tauhid biasanya memberi pembahasan sepihak dan tidak mengemukakan pendapat atau paham dari golongan-golangan lain. Ilmu tauhid yang diajarkan dan dikenal di Indonesia umumnnya adalah ilmu tauhid menurut aliran Asy'ariyyah, sehingga timbullah kesan di kalangan sementara umat Islam Indonesia, bahwa inilah satu-satunya teologi yang ada dalam Islam. Maka dari itu salah satu tujuan Harun Nasution dalam menulis buku "Teologi Islam” adalah untuk memperkenalkan aliran-aliran yang berlainan kepada umat

8 Harun Nasution, Teologi Islam ..., VII. 
Islam agar mereka mempunyai pemahaman yang kuat sehingga tidak mudah terombang-ambing oleh peredaran zaman. ${ }^{9}$

Tujuan lain Harun Nasution dalam menulis buku "Teologi Islam" adalah memberikan pandangan lain bagi para pembaca-pembaca yang biasanya mengetahui dan mengenal Islam hanya dari kacamata fikih atau hukum saja. Fikih menggambarkan Islam sebagai agama yang banyak membahas soal halal dan haram, sehingga timbul kesan bagi sebagian orang bahwa Islam adalah agama yang sempit, ketat dan kaku. Tentu pandangan demikian bukanlah pandangan yang benar. Islam sebenarnya bukan hanya mempunyai aspek fikih saja, tetapi ia juga mempunyai aspek-aspek yang lain, seperti aspek teologi, filsafat, mistik, tafsir, sejarah, sosial dan aspek yang lainnya. ${ }^{10}$

Dalam menyusun buku “Teologi Islam", Harun Nasution membaginya menjadi dua bagian. Bagian pertama Harun Nasution berusaha menjelaskan sejarah timbulnya persoalan-persoalan teologi dalam Islam. Menurut Harun Nasution, perselisihan tentang dosa besar, apakah dihukumi kafir atau tetap mukmin, telah melahirkan empat aliran besar dalam teologi Islam. Keempat aliran tersebut adalah aliran Khawarij, Murji'ah, Muktazilah dan Ahlu Sunnah wal Jama'ah. Hanya saja, jika kita mencermati pembagian sekte yang telah dipapakarkan Harun dalam bukunya, kita bakal menemukan kejanggalan. Ada yang tertinggal dalam pemaparan Harun Nasution. Ia tidak menyebutkan/menjelaskan Syi'ah sebagai salah satu sekte yang berkembang di masa itu. Penulis tidak yakin jika Harun Nasution lupa memasukkan Syiah ke dalam salah satu sekte Islam di dalam bukunya. Hal ini karena Harun Nasution juga menggunakan referensi yang menjelaskan Syiah sebagai salah satu sekte yang berkembang awal Islam, seperti buku triloginya Ahmad Amin, buku Milal wa Nihal karya Syahrastani, buku Maqalat Islamiyyin milik Abu Hasa al-Asya'ri dan buku al-Farqu bain al-Firaq karya al-Baghdadi.

\footnotetext{
9 Ibid., X.
}

10 Ibid., XI. 
Penulis menduga bahwa menghilangnya Syi'ah dari buku Harun Nasution karena ia memecah sekte dalam Islam berdasarkan sikap mereka terhadap pelaku dosa besar, Apakah tetap dihukumi sebagai seorang mukmin atau kafir. Menurut Harun Nasution, persoalan dosa besar ini menimbulkan tiga aliran teologi dalam Islam. Pertama aliran Khawarij yang mengatakan bahwa pelaku dosa besar dihukumi kafir, kedua aliran Murji'ah yang mengatakan bahwa pelaku dosa besar masih tetap dihukumi mukmin, dan yang ketiga aliran Muktazilah yang menempatkan pelaku dosa besar di antara ke dua posisi antara mukmin dan kafir (manzilah bain al-manzilatain).

Di bagian kedua dari buku Teologi Islam, Harun Nasution mencoba memberikan analisa dan perbandingan diantara aliran-aliran yang ada dalam Ilmu Kalam. Sebenaranya perbandingan dan analisa telah dilakukan pada bagian yang pertama, hanya saja analisa tersebut masih bersifat insidentil dan sepintas lalu saja. Uraian pada bagian kedua bermaksud memberikan perbandingan secara mendalam.

Padabagiankeduaini, Harun Nasution mencobamembandingkan antara peran akal dan wahyu, serta pendapat setiap aliran tentang kekuasaan akal dan fungsi wahyu. Selain itu, Harun Nasution juga melakukan analisa perbandingan antara kebebasan manusia dan kehendak mutlak Tuhan, yang kemudian ia menghubungkannya dengan konsep keadilan Tuhan. Pada bab-bab terakhir Harun Nasution berusaha menjelasakan sifat-sifat Tuhan dan konsep iman.

\section{Teologi Islam: Antara Politik dan Agama.}

Membahas teologi Islam dari aspek agama, politik maupun disiplin kelimuan memang sangat menarik. Teologi Islam yang notabennya berkutat pada pembahasan agama yang suci ternyata tidak terlepas dari jeratan politik yang penuh tipu muslihat dan dosa. Agak aneh memang ketika teologi Islam muncul bukan karena wahyu, tetapi karena politik dan kekuasaan, inilah yang diherankan 
oleh Harun Nasution dalam bukunya Teologi Islam. ${ }^{11}$ Tepatnya ketika Muawiyyah tidak menerima pengangkatan Ali sebagai khalifah. Muawiyyah menduga Ali ikut ambil bagian dalam kematian Usman bin Affan. Sebagai anggota keluarga, tentu Muawiyyah tidak menerima hal ini, maka dari itu ia menuntut Ali untuk menyelidiki kematian Usman terlebih dahulu dan menemukan pembunuhnya, sebelum ia diangkat menjadi khalifah. Tetapi permintaan tersebut ditolak oleh pihak Ali, dan terjadilah peperangan antar keduanya yang dalam sejarah dikenal dengan perang Shiffin.

Sebenarnya perseteruan tersebut dimenanangkan oleh pihak Ali bin Abi Thalib. Tetapi sewaktu pasukan Muawiyyah terdesak dan mulai tampak tanda-tanda kekalahan, Muawiyyah meminta salah satu utusannya untuk meletakkan al-Quran diatas tombak, kemudian menunjukkannya kepada pasukan Ali dan meminta perdamaian atau tahkim. Permintaan tersebut dipenuhi oleh Ali dengan mengutus Abu Musa al-As'yari untuk melakukan perundingan tersebut, sedangkan dari Muawiyyah mereka megutus Amru bin Ash. Dalam perundingan tersebut kedua belah pihak diminta untuk melepas jabatannya sebagai kepala negara, kemudian dipilih kembali secara demokratis dan Adil. Sayangnya pelepasan jabatan tersebut hanya dilakukan oleh kelompok Ali, sedangkan dari Muawiyyah justru malah melakukan hal sebaliknya. Sewaktu Abu Musa al-Asya'ri mengumumkan pelepasan jabatan Ali sebagai kepala negara, justru dengan licik Amru bin Ash mengangkat Muawiyyah menjadi khalifah umat Islam menggantikan Ali.

Persoalan kekuasaan dan khilafah inilah yang menyebabkan umat Islam terpecah menjadi beberapa golongan, sekaligus menjadi cikal bakal munculnya aliran teologi dalam Islam. Muawiyyah yang tidak ingin kehilangan jabatan setelah merebutnya dari Ali dengan susah payah, terus berusaha mempertahankan kekuasaannya dengan membuat hadis palsu tentang keutamaan sahabat (selain Ali dan

11 Ibid., 1. 
keluarga Bani Hasyim) terutama Usman. Pemerintah Umayah juga menggunakan paham Jabariyyah untuk mengukuhkan legitimasinya. Paham Jabariyyah meyakini bahwa semua pekerjaan manusia berasal dari Tuhan, sehingga dengan itu Muawiyyah beralasan bahwa tindakannya memberontak Ali bukan berasal dari dirinya tetapi semua itu adalah takdir yang memang dikehendaki Tuhan. Dengan paham tersebut Muawiyyah berusaha meredam semua pemberontakan yang ingin menuntut dirinya, terutama dari umat Syi'ah. Pun Syi’ah, mereka juga banyak membuat hadis palsu tentang keutamaan Ali dan keluargannya. Bahkan Syi'ah yang ekstrim, mereka sampai menuhankan Ali bin Abi Thalib. ${ }^{12}$

Dari sini kita bisa melihat bagaimana politik bisa mengintervensi agama, kemudian mempengaruhi dan membentuk doktrin-doktrin keagamaan. Dengan melihat kenyataan sejarah, tentu ini bisa menjadi kajian dan renungan, apakah kita juga akan terus ikut berpolimik dalam pertentangan aliran dan madzhab seperti orang-orang terdahulu, ataukah kita bersikap saling menghargai dan menghormati terhadap perbedaan tersebut. Sebagaimana yang ada dalam sejarah, bahwa perbedaan yang terjadi atar madzhab agama tidak terlepas dari jeratan politik dan perebutan kekuasaan, bukan agama?! Dalam politik, agama seringkali hanya digunakan untuk melegitimasi dan melanggengkan kekuasaan mereka!

Ahmad Amin dalam bukunya Fajr al-Islam mengatakan, bahwa sebenarnya kelompok-kelompok Islam pertama seperti Khawarij, Syi'ah dan Murjiah semula merupakan golongan politik yang muncul akibat persoalan Khilafah.Tetapi kemudian mereka membawa permasalahan politik tersebut pada permasalahan agama. ${ }^{13}$ Senada dengan hal diatas, Harun Nasution juga mengatakan bahwa mereka pada mulanya membahas persoalan-persoalan politik, tetapi persoalan tersebut dengan cepat meningkat ke persoalan teologi. ${ }^{14}$

12 Ahmad Amin, Fajru al-Islâm (Kairo: Maktabah al-Usrah, 1997), 275.

13 Ibid., 279.

14 Ibid., 1. 
Permasalahan khilafah memang merupakan salah satu permasalahan inti dalam teologi Islam. Meskipun sebenarnya penulis tidak setuju jika permasalah ini dimasukkan dalam bahasan teologi, karena permasalahan ini lebih banyak politiknya dari pada ketuhanannya. Barangkali karena permasalahan khilafah merupakan penyebab munculnya aliran-aliran dalam teologi Islam, sehingga para ulama memasukkan permasalahan tersebut kedalam pembahasan teologi. Dalam sejarah Islam, hanya umat Syi'ah lah yang menjadikan khilafah atau imam sebagai rukun iman. Menurut mereka Imam merupakan pusat dua hal, yakni imam yang menggerakkan roda agama dan imam yang menggerakkan roda pemerintahan.

Jika kita berbicara masalah khilafah, kita pasti berbicara dua hal, pertama kita berbicara masalah imam atau khalifah, dan yang kedua kita berbicara masalah sistem pemerintahannya. Selama ini yang dibahas dalam Islam hanyalah masalah imamnya saja, belum masuk pada sistem pemerintahannya. Tentu ini harus dibedakan, karena setiap kelompok dalam Islam memiliki pendapatnya masingmasing, dan belum tentu setali tiga uang dalam memilih imam dan sistem pemerintahannya. Ada juga kelompok yang demokratis dalam memilih pemimpin tetapi sitem pemerintahannya Islam radikal. Begitu juga sebaliknya ada juga yang dalam memilih pemimpin kurang demokratis tetapi dalam sistem pemerintahannya menggunakan musyawarah. Maka dari itu, kita akan membahasnya lebih dalam tentang tata cara pemilihan pemimpin serta berbagai macam bentuk pemerintahan dalam Islam.

Khawarij sebenarnya adalah para pengikut Ali dan ikut melawan Muawiyyah dalam perang Shiffin. Tetapi semenjak Ali menerima perdamaian dari Muawiyyah, mereka keluar dari golongan Ali. Kata Khawarij berasal dari kata kharaja, yang dalam bahasa Arab berarti keluar. Orang-orang Khawarij adalah orang-orang yang keluar dari golongan Ali bin Abi Thalib. Mereka berpendapat bahwa apa yang dilakukan oleh Ali bin Abi Thalib tidak sesuai dengan Syariat. Munurut 
mereka hukum Allah sudah jelas, Muawiyyah adalah pemberontak dan apa yang dilakukannya merupakan tindakan makar pada pemerintahan yang sah. Melakukan perdamaian dan rekonsiliasi adalah tindakan yang salah, karena hal ini akan menimbulkan keraguan pada kedua belah pihak mana yang benar dan mana yang salah, sedangkan mereka berperang dengan keyakinan bulat bahwa merekalah yang benar. ${ }^{15}$

Orang-orang khawarij tidak hanya keluar dari Ali, tetapi mereka balik memusuhi Ali. Pun mereka juga memusuhi para tokoh tokoh yang ikut melakukan perundingan tahkim. Mereka juga mengkafirkan Abu Musa al-Asya'ri dan Amru bin Ash, keduaanya ini ditunjuk oleh masing-masing kelompok sebagai utusan perdamaian. Abu Musa al-Asyari ditunjuk oleh pihak Ali bin Abi Thalib dan Amru bin Ash diutus oleh pihak Muawiyyah. Tidak berhenti sampai disitu, Khawarij juga mengutus para pengikutnya untuk membunuh Ali, Muawiyyah dan Amru bin Ash. Tetapi mereka hanya berhasil membunuh Ali bin Abi Thalib melalui tangan Khariji yang bernama Abdurrahman ibn Muljam, sedangkan yang lain selamat.

Dalam diri khawarij, tertanam semboyan "Lâ Hukma Illa Allah" atau tidak ada hukum kecuali hukum Tuhan. Semboyan ini diambil dari surat al-Maidah ayat 45 yang artinya "barang siapa yang tidak berhukum dengan apa yang telah diturunkan Allah, maka mereka adalah orang- orang yang kafir”. Atas dasar inilah mereka berani mengkafirkan para Sahabat yang ikut dalam peristiwa tahkim. Mereka beranggapa bahwa tahkim atau perundingan yang dilakukan Ali dan Muawiyyah saat itu adalah produk manusia. Dengan melakukan tahkim, otomatis mereka telah berhukum dengan produk manusia dan berpaling dari al-Quran.

Hal yang berkebaikan dari Khawarij adalah cara mereka dalam memilih imam atau khalifah. Khawarij dianggap sekte yang paling demokratis dalam memilih imam, karena memberikan semua rakyat hak nya dalam menjadi imam. Hal ini cukup mengejutkan, karena

15 Ibid., 256. 
dalam perilaku mereka dikenal sebagai orang-orang yang radikal. Menurut mereka, khalifah atau imam harus dipilih secara bebas oleh seluruh umat Islam. Yang berhak menjadi khalifah bukanlah anggota suku bangsa Quraisy saja, bahkan orang yang bukan orang Arab pun berhak menjadi khalifah meskipun seorang hamba sahaya. Tetapi dengan syarat ia harus Islam, adil dan menjalankan syari'at Islam. Kalau ia menyeleweng dari syari'at Islam maka ia harus dijatuhkan atau dibunuh. ${ }^{16}$

Bersdasarkan keterangan diatas, orang-orang Khawarij, menerima kepemimpinan serta pemerintahan Abu Bakar dan Umar, karena dianggap tetap menjalankan syari'at Islam. Sedangkan Usman bin Affan dianggap telah menyeleweng sejak tahun ke tujuh masa kekhalifahannya, karena dugaan nepotisme. Begitu juga dengan Ali bin Abi Thalib dianggap menyeleweng setelah peristiwa tahkim (arbitrase). Sejak itulah Usman dan Ali dicap sebagai orang kafir, beserta Muawiyyah, Amr bin Ash, Abu Musa al-As'ary dan semua orang yang mreka anggap telah melanggar ajaran-ajaran Islam. ${ }^{17}$

Tidak semua pengikut Ali keluar dari golongan Ali setelah peristiwa tahkim (baca: rekonsiliasi). Ada juga golongan yang masih setia bersama Ali, bahkan kesetiaannya sampai pada puncak kefanatikan. Mereka adalah golongan yang terkenal dengan sebutan Syi'ah. Orang Syi'ah adalah orang-orang yang meyakini kepemimpinan dan kekhalifahan Ali, baik secara nash maupun secara wasiat, secara tampak atau tersembunyi. Orang Syi'ah mempunyai keyakinan bahwasannya Imam tidak boleh keluar dari keluarga Ali. Menurut mereka masalah khilafah atau imam bukanlah masalah maslahat yang harus dipilih oleh orang banyak, tetapi khilafah adalah masalah agama. Bagi Syiah masalah imamah sudah menjadi tiang agama, sehingga mereka beranggapan bahwa Nabi tidak mungkin mengabaikannya, apalagi sampai lupa. Mereka berkeyakinan bahwa Nabi sebenarnya telah berwasiat sebelum meninggal, dan yang diwasiati adalah Ali.

16 Harun Nasution, Teologi Islam ..., 1.

17 Ibid., 12. 
Maka dari sini kemudian muncul teori kekhalifahan atas dasar Nash dan wasiat. Para ulama Syi'ah telah bersepakat tentang hal itu. ${ }^{18}$

Syi'ah dilihat dari pandangan mereka terhadap imamah dapat digolongkan sebagai penganut teokrasi. Tetapi sebenarnya para ahli sejarah baru membahas Syi'ah dari segi mekanisme pemilihan imam, penulis melihat bahwa para ahli sejarah kurang menekankan sejarah Syi'ah pada sistem pemerintahannya. Sebenarnya ada beberapa dinasti yang menggunakan ideologi Syi’ah dalam pedoman kenegaraannya, seperti Kerajaan Idrisi (788-877M) di Maroko yang didirikan Idris bin Abdullah, dinasti Fatimiah di Tunisia (909M) yang kemudian menguasai Mesir tahun 969 M, Dinasti Buwaihi di Persia , dinasti Buwaihi di Persia yang kemudian dapat menguasai Baghdad tahun 945M-1055M, kerajaan Safawi di Persia (1252-1334M), dan terakhir Negara Republik Islam Iran yang berkuasa di Negara Iran (dahulu bernama Persia) hingga sekarang. ${ }^{19}$ Dalam prakteknya, umat Syi'ah tetap menggunakan musyawarah dalam mengatur pemerintahan. hal ini bisa kita lihat pada sistem wilayatul fakih pada pemerintahan Iran, sistem ini hampir menyerupai demokrasi parlementer yang ada di Indonesia sebelum reformasi.

Orang-orang Syi'ah semakin fanatik setelah Ali dilengserkan oleh Muawiyyah. Dalam beberapa kesempatan mereka berusaha merebut kekuasaan yang telah hilang dari pemerintah setempat. Tapi usahanya seringkali menemui kegagalan, mereka justru dikejarkejar sampai keujung dunia dan dibantai. Sehingga mereka terpaksa melakukan taqiyyah ataau menyembunyikan jati diri mereka sebagai seorang Syi'ah, serta untuk menyelamatkan Syi'ah dari kepunahan. Mereka meyakini bahwa yang pantas menjadi khalifah adalah Ali dan keluarganya. Menurut mereka khalifah atau imam tidak dipilih oleh manusia, tetapi dipilih oleh Tuhan. Imam bagi mereka adalah ma'sum, yaitu seorang imam terjaga dari kesalahan dan dosa.

18 Syahrastani, Al-Milâl wa an-Nihal (Beirut : Dâr Ibnu Hazm, Cet 1, 2005), 96.

19 Harun Nasution, Islam ditinjau dari berbagai aspeknya, (Jakarta: Universitas Indonesia Press, Cet 5, 1985), 75-84. 
Ditengah pergolakan yang sengit antara kelompok yang mendukung Ali dan Muawiyyah, terdapat kelompok yang yang tidak memihak keduannya. Sebagaimana yang dikatakan Ibnu Asakir golongan ini muncul dengan mengambil sikap kompromi dan tidak memihak satu sama lain. Mereka beranggapan bahwa Khawarij, Syi'ah maupun pengikut Muawiyah adalah mu'min, meskipun mereka telah melakukan kesalahan. Kelompok ini kemudian dikenal dengan nama Murji'ah. Kata Murji'ah berasal dari kata arja'a yang berarti menunda. Maksudnya mereka menunda persoalan-persoalan dosa besar dan keimanan di hari kiamat nanti.

Menurut Ahmad Amin, sikap Murji'ah yang netral ini secara tidak langsung telah memberi dukungan kepada golongan Umayah yang berkuasa saat itu, meskipun dukungan yang mereka lakukan bersifat pasif dan tidak aktif. Mereka memang tidak terang-terangan memihak kepada Umayah dan juga tidak ikut berperang bersama Bani umayyah, tetapi mereka memandang

Sebagaimana yang dikatakan Ahmad Amin dalam bukunya Fajr Islam, bahwa Secara tidak langsung sikap mereka ini Mereka, tetapi sikap mereka kepada golongan Umayah sama dengan sikap mereka kepada golongan Syi'ah dan Khawarij. Mereka menurut pengamatan Ahmad Amin mamandang pemerintah Umayah sebagai pemerintahan yang sah, dan ini sudah cukup memberi dukungan kepada mereka. ${ }^{20}$

Selain ketiga paham diatas, ada lagi paham yang muncul agak belakangan yaitu paham Muktazilah yang muncul pada awal abad ke dua Hijriyyah. Kaum Muktazilah adalah golongan yang membawa persoalan-persoalan teologi dengan pembahasan yang lebih mendalam dan bersifat filosofis dari pada persoalan-persoalan yang dibawa kaum Khawarij dan Murji'ah. Dalam pembahasannya mereka banyak menggunakan akal dan logika sehingga mereka mendapat julukan "kaum rasionalitas Islam". ${ }^{21}$

20 Ahmad Amin, Fajru al-Islâm., 280.

21 Harun Nasution, Teologi Islam., 38. 
Nama Muktazilah diambil dari kata I'tazala yang artinya berpisah. Menurut al-Baghdadi, waktu itu Washil dan temannya Amru bin Abid berdebat dengan gurunya Hasan al-Bashri tentang masalah dosa besar. Hasan al-Bashri berpendapat bahwa orang yang melakukan dosa besar adalah tetap mukmin, meskipun ia akan dihukum di neraka karena dosanya. Tetapi Washil bin Atha' menolak pendapat demikian, ia berpendapat bahwa orang yang melakukan dosa besar berada di manzilah bain al-manzilatain atau tempat diantara dua tempat. Karena tidak ada kesepakatan dalam hal tersebut, Washil dan Amru bin Abid memilih memisahkan diri dengan gurunya, dan mendirikan kelompok agama tersendiri. Sejak saat itu, kelompok Washil dikenal dengan aliran Muktazilah.

Dalam buku Milal wa Nihal karya Syahrastani, ada empat ajaran yang diajarkan Washil bin Atha' dalam sekte Muktazilah. Pertama nafyu sifat, yaitu paham yang berusaha meniadakan sifat Tuhan seperti Ilmu, Qudrah, Iradah dan Hayyah. Sifat ini dihilangkan karena akan menyebabkan dualisme dalam diri Tuhan. Kedua paham qadariah, Paham ini berasal dari Ma'bad al-Juhni dan Ghilan al-Damsiqy. Paham ini mengajarkan bahwa manusia lah yang mewujudkan perbuatan baik dan buruknya, bukan Tuhan. Ketiga, Paham manzilah bain almanzilatain, bahwa orang yanng berbuat dosa besar berada diantara mukmin dan kafir. Dan keemapat adalah paham yang menyatakan bahwa diantara kelompok dalam perang Jamal dan Siffin, salah satunya pasti ada yang bersalah. Tetapi ajaran tersebut tidak menentukan mana yang salah diantara kelompok-kelompok yang ada. ${ }^{22}$

Pada periode berikutnya ajaran Muktazilah kemudian berkembang menjadi lima ajaran yang terkenal dengan sebutan ushul al-khamsah, yaitu Tauhid, al-Adl (keadilan), Manzilah bain Manzilatain, al-Wa'du wal Wa'id (janji dan ancaman), dan amar ma'ruf nahi munkar. Menurut Qadhi Abdul Jabbar, orang yang berpaling dari lima madzhab tersebut bisa dianggap sebagai kafir, Fasiq atau Mukhti'

22 Syahrastani, Al-Milâl wa an-Nihal., 35. 
(salah). Orang dianggap kafir jika mengingkari tiga dasar ushul alkhamsah, yaitu tauhid, Adil, dan wa'du wal wa'id. Sedangkan orang yang membangkang terhadap ajaran manzilah bain manzilatain, mereka disebut sebagai orang fasiq. Adapun orang yang membantah ajaran amar ma'ruf nahi mungkar, maka ia termasuk dalam golongan mukhti' (orang yang bersalah). ${ }^{23}$

Dalam hal imamah, Muktazilah berpendapat tentang keharusan imam dalam sebuah pemerintahan atau negara. Karena Imam dibutuhkan sebagai pelaksana hukum syariat, seperti menegakkan hukum, mempersiapkan tentara, pemimpin perang, dan pelindung agama. Dalam memilih calon pemimpin Muktazilah mensyaratkan empat hal, pertama seorang pemimpin harus berasal dari golongan khusus, yang mempunyai kedudukan tertentu. Kedua pemimpin harus cerdas dan pandai, ia harus tahu hukum. Ketiga pemimpin harus bisa menjaga kehormatan dirinya. Keempat pemimpin harus berani, kuat pedirian dan percara diri. Cara memilih pemimpin menurut Muktazilah harus dipilih secara demokratis dan dibaiat. ${ }^{24}$

Munculnya Muktazilah yang belandaskan pada logika, memicu lahirnya kelompok baru yang berlandaskan pada Sunnah dan Hadis Nabi. Aliran tersebut kemudian dikenal dengan nama Ahlu Sunnah wal Jama'ah. Menurut Harun Nasution, Ahlu Sunnah mucul sebagai akibat reaksi terhadap golongan Muktazilah yang menganut faham qadariyyah. ${ }^{25}$ Kelompok Ahlu Sunnah mulai menampakkan dirinya setelah pemerintahan Ma'mun yang berideologi Muktazilah melakukan tindakan mihnah. ${ }^{26}$ Pada waktu itu, khalifah Ma'mun mewajibkan

23 Abdurrahman Badawi, Madzâhib al-Islâmiyyin (Beirut: Dâr al-Ilmi li al-Malâyîn, 1997), 57.

24 Abdul Jabar bin Ahmad, Syarh al-Ushûl al-Khamsah (Kairo: Al-Hai'ah al-Mishriyyah al-Âmmah li al-Kitâb, 2009), 750-758.

25 Harun Nasution, Teologi Islam., 61.

26 Kata mihnah berasal dari bahasa Arab yang berarti ujian. Jadi sewaktu Al-Makmun berkuasa, ia mewajibkan rakyat nya untuk menganut ajaran Muktazilah terutama paham yang mengatakan al-Quran sebagai mahluk Tuhan, dan bukan kalam Tuhan yang qadim. Maka dari itu, ia memerintahkan kepada para pejabat istana untuk menguji keyakinan yang dianut para ulama saat itu. Jika terbukti ada ulama yang mengingkari keyakinan tersebut yakni mengingkari bahwasannya al-Quran adalah mahluk, maka ia harus dihukum. 
kepada siapa saja untuk mengatakan bahwa al-Quran adalah mahluk (ciptaan Tuhan seperti hal nya manusia dan alam). Tentu hal ini ditolak oleh kelompok yang masih berpegang pada sunnah. Menurut mereka al-Quran adalah kalam Allah yang qadim (dahulu), tidak seperti yang dikatakan kaum Muktazilah.

Salah satu ulama yang dipanggil dalam peristiwa mihnah adalah Ahmad bin Hambal. Beliau adalah salah seorang Ahli hadis yang sangat terkemuka, maka dari itu ia menolak dengan tegas ajakan yang menyatakan al-Quran adalah makhluq. Ia tetap berkeyakinan bahwa al-Quran adalah kalam Allah yang qadim. Demi mempertahankan keyakinannya, ia rela dihukum dan dipenjara hingga mati. Maka dari itu, terma Ahlu Sunnah selalu identik dengan Ahmad bin Hambal, karena beliau adalah simbol perjuangan Ahlu Sunnah terhadap ideologi Muktazilah waktu itu.

Ada tiga tokoh penting yang dianggap sebagai pemrakarsa dan pendiri aliran Ahlu Sunnah. Tokoh-tokoh tersebut adalah Imam Ahmad bin Hambal, Abu Hasan al-Asy'ari dan Maturidi. Dalam Kitab Al-Ibânah an Ushûl al-Diyânah, Abu Hasan al-Asy'ari melandaskan Ahlu Sunnah wal Jamaah pada empat hal, yaitu Al-Quran, Sunnah, Riwayat Sahabat, Tabi'in dan Ahlu Hadis, dan yang terakhir berlandaskan pada perkataan Imam Ahmad bin Hambal. ${ }^{27}$

Dalam hal politik terutama dalam hal Imamah, orang-orang Ahlu Sunnah berpendapat bahwa pemerintahan Abu Bakar adalah pemerintahan yang sah, karena ia dibaiat oleh dua orang sekaligus yang dianggap menolak kekhalifaahan Abu Bakar, keduanya adalah Ali dan Abbas. Dengan demikian Ahlu Sunnah menolak pandangan yang menyatakan bahwa imam haruslah dengan nash. Kaum Ahlu Sunnah lebih sepakat jika pemilihan imam didasarkan pada musyawarah dan baiat. $^{28}$

27 Abu Hasan al-Asy'ary, Al-Ibânah an Ushûl al-Diyânah (Bairut: Dar al-Kutub alIlmiyyah, cet 3, 2005), 15 .

28 Abu Hasan al-Asy'ary, Al-Luma' fi al-Raddi 'ala Ahli Zaigh wa al-Bida' (Kairo: Maktabah al-Azhariyah li al-Turast), 130. 


\section{Pertarungan Antara Akal dan Wahyu}

Perdebatan tentang lebih unggul mana antara akal dan wahyu telah berlangsung sejak lama dalam agama Islam. Bahkan perdebatan ini berlangsung dalam berbagai bidang keilmuan seperti tafsir, hadis, fikih dan tentunya ilmu kalam itu sendiri, dengan munculnya ahli ra'yi dan ahli hadis. Harun Nasution mengatakan bahwa perdebatan antara akal dan wahyu dalam ilmu kalam berpokok pada dua persoalan yaitu bagaimana manusia mengetahui Tuhan dan bagaimana mengetahui hal yang baik dan yang buruk?! Apakah akal mampu melakukan kedua hal tersebut ataukah harus dengan bantuan wahyu?!

Daripermasalahantersebut,kemudianmunculduapermasalahan lagiyangmasing-masing munculdarikeduanya, sehinggapermasalahan pokok ilmu kalam klasik menjadi empat permasalahan. Pertama, jika akal mampu mengetahui Tuhan, maka apakah manusia harus (wajib) berterimakasih kepada Tuhan meski belum atau tidak ada wahyu?! Kedua, Jika akal dapat mengetahi perbuatan yang baik dan buruk, maka apakah manusia wajib melakukan hal baik meski belum ada wahyu?! Persoalan tentang kewajiban berterimakasih kepada Tuhan dan kewajiban berbuat kebaikan merupakan dua persoalan tambahan yang muncul dari dua permasalahan sebelumnya.

Harun nasution menguraikan pendapat mengenai pertarungan akal dan wahyu ini menjadi tiga aliran besar yaitu Muktazilah, Asy'ariyah dan Maturidiyyah. Tetapi pendapat Maturidiyyah ini terpecah menjadi dua golongan yaitu Maturidiyyah Samarkand dan Maturidiyyah Bukhara.

Bagi Muktazilah segala pengetahuan dapat diketahui dengan akal, begitu juga pengetahuan tentang adanya Tuhan dapat diperoleh melalui akal. Maka dari itu, manusia wajib berterimakasih kepada Tuhan yang telah menciptakan manusia dan alam seisinya. Meski belum ada wahyu, Muktazilah mengatakan bahwa manusia tetap mempunyai kewajiban berterimakasih kepada Tuhan, dan barang siapa yang tidak berterimakasih maka mereka akan diadzab Tuhan 
di neraka. Berterimakasih kepada Tuhan disini maksudnya bisa beribadah, bersyukur dan sebagainya.

Dalam hal bagaimana manusia mengetahui hal yang baik dan buruk, Muktazilah berpendapat sama. Menurutnya, Manusia dapat mengetahui perbuatan yang baik dan yang buruk dengan akal. Maka dari itu, manusia mempunyai kewajiban pula untuk melakukan perbuatan yang baik dan meninggalkan yang buruk, dengan atau tanpa adanya wahyu. Dan barang siapa yang melakukan sebaliknya, yakni melakukan keburukan dan meninggalkan kebaikan, ia akan dihukum oleh Tuhan.

Pertanyaannya, apakah wahyu masih diperlukan bagi Muktazilah jika semua hal telah dapat diketahui oleh akal?! lalu apa fungsinya wahyu?! Dalam hal ini Muktazilah berpendapat bahwa wahyu tetap diperlukan. Memang dengan akal, kita dapat mengetahui segalanya, termasuk mengetahui adanya Tuhan, perbuatan yang bai dan yang buruk dan seterusnya, tetapi akal tidak dapat mengetahui perinciannya. Akal mampu mengetahu bahwa Tuhan ada di alam ini, tetapi akal tidak mampu mengetahui Tuhan secara rinci, termasuk sifat-sifat Tuhan. Akal juga tidak mampu mengetahui bagaimana caranya berterimakasih kepada Tuhan secara rinci seperti shalat, zakat, puasa, haji dan sebagainya. Jadi Muktazilah berpendapat bahwa wahyu tetap diperlukan, karena akal hanya dapat mengetahui yang umum saja, tidak sampai pada hal-hal yang rinci.

Dari uraian diatas, sebenarnya wahyu bagi Muktazilah lebih banyak berfungsi sebagai konfirmasi dari pada informasi. Menurut Albert Nader bahwa syari'ah aqliyyah pada hakikatnya tidak berbeda dengan syari'at nabawiyyah, bahwa syari'ah nabawiyyah datang untuk memperkuat dan menyempurnakan syari'ah aqliyyah. ${ }^{29}$

Pendapatyang bertentangan dengan Muktazilah adalah pendapat Asy'ariyyah. Wahyu bagi kaum Asy'ariyyah mempunyai fungsi yang banyak sekali. Maka dari itu wahyu dalam Asy'ariyyah mempunyai

29 Harun Nasution, Teologi Islam., 100. 
kedudukan yang sangat penting, karena akal hanya mampu mengetahui adanya Tuhan. Selain itu, praktis semuanya membutuhkan wahyu. Akal tidak dapat mengetahui kewajiban berterimakasih kepada Tuhan. Ia juga tidak mampu mengetahui hal yang baik-dan yang buruk, apalagi mengetahui kewajiban berbuat kebaikan dan meninggal kan keburukan. Maka dari itu, Tuhan mengirim rasulnya untuk mengajari manusia dengan wahyu.

Adapun pendapat kaumMaturidiah terpecah menjadi dua golongan, yaitu golongan Samarkand dan golongan Bukhara. Menurut golongan Samarkand, manusia dapat mengetahui Tuhan dengan akal, maka dari itu manusia wajib berterimakasih kepad Tuhan. Golongan Samarkand juga berpendapat bahwa akal dapat mengetahui yangbaik dan yang buruk, akan tetapi akal tidak bisa mewajibkan manusia untuk berbuat baik. Dengan demikian golongan ini sebenarnya lebih dekat dengan golongan Muktazilah, meskipun mereka tidak sepakat dengan kewajiban berbuat baik dengan berdasarkan akal.

Sedangkan golongan Bukhara berpendapat bahwa melalui akal, manusia dapat mengetahui tentang adanya Tuhan dan perbuatan yang baik dan buruk. Tetapi akal tidak dapat menjadi landasan kewajiban dalam berterimakasih kepada Tuhan maupun kewajiban berbuat kebaikan. Meskipun akal bisa mengetahui yang baik dan yang buruk, tetapi kewajiban berbuat baik dan larangang berbuat buruk yang menentukan wahyu.

\section{E. Penutup}

Kehadiran Harun Nasution memberikan gairah tersediri dalam diskursus teologi Islam di Indonesia. Bisa dianggapia merupakan tokoh pembaharuan yang menjembatani beralihnya pembahasan teologi klasik menuju teologi yang lebih modern.Jika pembahasan teologi klasik di sejak awal pembahasannya, telah melakukan pembelakukan pembelaan terhadap salah satu sekte tertentu, maka teologi yang 
diajarkan Harun Nasution berusaha menjelaskan seobjektif mungkin di antara berbagai aliran yang ada dalam teologi Islam.

Dalam menjelaskan pertrungan antara wahyu dan akal, Harun Nasution membelahnya menjadi tiga pendapat, yaitu pendapat Muktazilah, Asy'ariyyah dan Maturidiyyah. Muktazilah berpendapat bahwa dengan akal saja sebenarnya manusia sudah mampu menemukan hakikat Tuhan dan mampu mengetahui yang baik dan yang buruk, karena itu wahyu bagi Muktazilah hanya berfungsi sebagai konfirmasi kebenaran akal. Sebaliknya kaum Asy'ariyyah berpendapat bahwa hakikat Tuhan serta perbuatan yang baik dan yang buruk hanya bisa diketahui dengan wahyu. Adapun Maturidiyyah berada diantara keduanya, gologan ini terpecah menjadi dua yaitu golongan Samarkhand dan golongan Bukhara, golongan Samarkhand lebih dekat ke Muktazilah, sedangkan golongan Bukhara lebih dekat ke Asy'ariyyah.

\section{Daftar pustaka}

Al-Asy'ary , Abu Hasan, Al-Luma' fi al-Raddi 'ala Ahli Zaigh wa al-Bida', Kairo: Maktabah al-Azhariyah li al-Turast , Al-Ibânah an Ushûl al-Diyânah, Bairut: Dar alKutub al-Ilmiyyah, cet 3, 2005

Amin, Ahmad, Dhuha Islam, Kairo: Maktabah al-Usrah, 1997 , Fajru al-Islâm, Kairo: Maktabah al-Usrah, 1997

Badawi, Abdurrahman, Madzâhib al-Islâmiyyin, Beirut: Dâr al-Ilmi li al-Malâyîn, 1997

Jabar bin Ahmad, Abdul, Syarh al-Ushûl al-Khamsah, Kairo: Al-Hai ah al-Mishriyyah al-Âmmah li al-Kitâb, 2009

Nasution, Harun, Islam ditinjau dari berbagai aspeknya, Jakarta: Universitas Indonesia Press, Cet 5, 1985 
Teologi Islam, Jakarta: Universitas Indonesia Press, Cet 5, 1986

Sunanto,Musyrifah, Sejarah Islam Klasik, Jakarta: Kencana, Cet 3, 2007 Syafi'i, Hasan Mahmud, Al-Madkhal ilâ Dirâsat Ilmi al-Kalâm, Kairo: Makatabah Wahbah, Cet 2, 1991

Syahrastani, Al-Milâl wa Nihal, Beirut : Dâr Ibnu Hazm, Cet 1, 2005 